\title{
Microbial Quality of Common Restaurant Foods: Food Safety Issue in Bangladesh
}

\author{
Zubaer Hosen ${ }^{1,}$, , Sabiha Afrose ${ }^{2}$ \\ ${ }^{1}$ Department of Applied Nutrition and Food Technology, Islamic University, Kushtia, Bangladesh \\ ${ }^{2}$ Department of Pharmacy, Islamic University, Kushtia, Bangladesh
}

Email address:

zubaeranftiu@gmail.com (Z. Hosen), sabihahosen@gmail.com (S. Afrose)

${ }^{*}$ Corresponding author

To cite this article:

Zubaer Hosen, Sabiha Afrose. Microbial Quality of Common Restaurant Foods: Food Safety Issue in Bangladesh. Journal of Food and Nutrition Sciences. Vol. 7, No. 4, 2019, pp. 56-59. doi: 10.11648/j.jfns.20190704.11

Received: September 23, 2019; Accepted: September 24, 2019; Published: October 10, 2019

\begin{abstract}
Street and restaurant foods play an important role in people's daily food options as well as their regular nutritional requirements are dependent on these foods, as their ever-growing busy schedule take away the opportunity to eat homemade food. Due to expedient availability, these street and restaurant foods are one of the primary food options for city people. Over the years, many food-borne diseases have been reported due to contaminated non-homemade food consumption. This study was conducted to analyze the microbiological quality of foods which are sold in street side food premises, general restaurants and higher class restaurants. This research study observed, and analyzed the microbiological quality of thirteen most commonly consumed food items of street side food premises, general restaurants and higher class restaurants from Kushtia and Jhenidah town in south-west region of Bangladesh. Higher percentages of microbial contamination were observe in street side food premises ( $76.92 \%$ for gram-positive bacteria, $69.23 \%$ for gram-negative bacteria and $61.54 \%$ for fungi). It has been found out that, instant cooked food items showed less microbial load than raw or preserved food. Higher class restaurants foods showed less microbial load than street side food premises and general restaurants. This study specifically highlights the level of microbial presence found in various available non-homemade foods. Finally, this study recommends some preventive measures which the government and food-maker together should follow, and also maintain the standard hygienic procedure to prepare, cook and handle foods. Implementation of such measures, rules and regulations on street food vendors and restaurant foods are extremely crucial to maintain the hygienic condition as well as to avoid such spreading of harmful organisms through consumption of contaminated foods.
\end{abstract}

Keywords: Food Borne Disease, Bacteria, Fungi, Food Safety, Hygiene, Sanitation Management

\section{Introduction}

Microbial food borne illness is major health concern worldwide. Unsafe food creates global health threats and poses a threat to the health of every person. Children, pregnant women, old people and people with a disease are the most vulnerable. South-East Asia Region has the second highest burden of foodborne diseases per population, after the African Region. 60 million children under the age of 5 fall ill and 50000 die from foodborne diseases in the SouthEast Asia Region every year [1]. The provision of safe food for children and adolescents of school going age is of great concern to governments and other stake holders as it improves health, growth and development of beneficiaries and encourages continued education in developing countries [2-5]. Low educational qualifications, socioeconomic status, lack of knowledge of safe food handling, vendor's mobility, diversity, temporary nature also contribute to public health risk [5]. Foodborne diseases (FBD) is a common health hazard worldwide, an outcome of poor hygiene practices [68]. Diarrhea is most food bone common disease and approximately 30 million people are suffering from food borne illness each year in Bangladesh. Multidrug resistant food borne microorganisms made the food safety situation more vulnerable in public health [9].

Bangladeshi peoples are depends on street side food premises (SFP), general restaurants (GR) and Higher Classes Restaurants 
(HCR) as their sources of food consumption besides households. Microbial food borne illness is highly associated with street foods [9]. Mainly people from low socioeconomic bracket and students are most popular consumers of street foods [10]. Street foods are prepared and stored in dirty environment, near contaminated sources and most of the time street foods are not covered and exposed to flies and dust which cause food borne diseases due to consumption [5].

Contamination of street foods persists through preparation and cooking due to the quality of raw materials [11]. Lack of potable water for various activities vendors re-use the water for cleaning utensils and used dishes; this has been reported in various continents like Asia, Africa and South America [11]. Staphylococcus spp. contamination of utensils often occur at vending site due to touch the food after touching the dish washing cloths and water after dish washing and hand washing, which indicates cross contamination of dish water, food preparation surfaces and the street foods [12]. In developing countries most of the street food vendors have less general perception of food safety issues, inadequate knowledge on proper food handling and their role in the transmission of pathogens due lack of formal education or have few years of schooling [12]. Report indicate that multiple food items from street of Salem district of Tamil Nadu, India showed more viable microbial count (spores, yeast, Gram - ve rod and Gram + ve cocci) than same homemade food items, due to unhygienic food preparation and storage at appropriate temperatures, exposure to flies, dust, wind and other contaminants [13].

Salad is the most popular food items with streets and others restaurants food items. Reports indicate that two large outbreaks in the United Kingdom demonstrated the significant health problems that could arise from consumption of contaminated salads [14]. Another main issue is simply the availability of adequate safe water, which is usually a critical item in the spreading of diseases [15]. Epidemiological evidence indicates that cholera is primarily a waterborne disease [16]. The microbial load and the presence of the bacterial pathogens in foods are a good indication of the food quality and the potential health risk they pose to consumers [17].

Ensuring Food safety and high quality management are the great challenge to developing countries like Bangladesh. People should be aware about the causes of food borne diseases, food safety, sanitation management and hygiene practice. This study has been conducted to assessment of microbial quality of foods from different food premises where peoples are consume foods in daily basis, aware the consumers and food handlers about the health risk of food borne diseases and ensure the practices regarding food hygiene, safety, sanitation management.

\section{Materials and Methods}

\subsection{Sample Collection}

In this study, a total of 78 food samples were collected for the assessment of bacteriological and fungal presence and identification. Samples were collected from the different food premises in Kushtia and Jhenida city, Bangladesh. The food samples were collected from food premises on Thursday afternoon between $1: 00 \mathrm{pm}$ and $2: 30 \mathrm{pm}$. The time interval between sampling from each vendor was approximately 1520 minutes. I collected 10 samples on every sampling day. Food samples included cereal based (Rice), cooked food (Meat, Fish, Egg, Dal, Singara, Peaju, and Puri), vegetable (Salad and Mixed vegetables) and drinks (Fruit juice and Water). Approximately $200 \mathrm{~g}$ of each food sample was collected using the vendors serving utensils, took the samples in a zipper bag and quickly sent them in the ice box to inhibit the microbial contamination after sample collection. Food temperatures were recorded at the time of sampling using a portable thermometer. In the laboratory stored at $4^{\circ} \mathrm{C}$ until testing. They were analyzed within 24 hours of sampling.

\subsection{Sample Processing}

All samples were collected in sterile polythene bag and plastic bottle in an insulated box and with ice to maintain a temperature ranging from $4{ }^{\circ} \mathrm{C}$ to $6^{\circ} \mathrm{C}$ and analyzed within one hour after procurement. From each sample, $25 \mathrm{~g}$ was aseptically weighed and macerated and $225 \mathrm{ml}$ of sterile saline water $(0.9 \%)$ was added to the salad under laminar air flow to prepare stock solution. Sterile Serial dilution was carried out using sterile distilled water as diluents. Seven sterile test tubes were taken each containing $9 \mathrm{ml}$ of sterile distilled water. Test tubes were labeled by 10-1 to 10-5. Before making any dilution, each of the water samples was shaken vigorously. $1 \mathrm{ml}$ of stock solution was added to a testtube containing $9 \mathrm{ml}$ of sterile water and thoroughly mixed to get a 10-1 dilution of the stock solution. $1 \mathrm{ml}$ of 10-1 dilution was transferred to $9 \mathrm{ml}$ of sterile water in another test tube and thoroughly mixed to get a 10-2 dilution. In such way serial dilution of stock solution were made up to 10-5.

\subsection{Microbial Identification}

Isolation of bacteria and fungi were done by growing them on selective and non-selective media such as Nutrient Agar (NA) for bacteria and incubate at $32-35^{\circ} \mathrm{C}$ for about $18-48$ hours, after which the plate was examined to detect bacterial growth. Then gram staining was performed to identification of gram positive and negative bacteria by violate and pink color. Potato Dextrose Agar (PDA) for fungi plate and incubated at room temperature for about four days, after which the plate was examined to detect fungal growth.

\section{Results}

\subsection{Microbiological Analysis of Food Samples}

The microbial analysis of various food collected from different food premises in Kushtia and Jhenidah cities are presented in Table 1. In this study, 13 types of food samples including Rice, Meat, fish, vegetable, egg, singara, puri, dal, piaju, salad, fruit juices, sauces and drinking water were 
tested for assessment of the microbial presence in these items. I categorized the food premises as street side food premises (SFP), general restaurants (GR) and Higher Classes Restaurants (HCR). A significant number of gram positive and negative bacteria were present in rice, vegetable, singara and salad among all food premises. Besides, singara, puri and salad containing higher number of fungi among all food premises. Dal, sauces and drinking water from street side food premises contain higher microbial load than other food premises groups. This study also found and observed that overall all food premises have not good hygiene practice that's why the food sample from all classes of food premises containing microbial load specially bacteria and fungi.

Table 1. Microbial analysis of various foods in Kushtia and Jhenidah city.

\begin{tabular}{|c|c|c|c|c|c|c|c|c|}
\hline \multirow{2}{*}{$\begin{array}{l}\text { Types of } \\
\text { Microorganisms }\end{array}$} & \multirow{2}{*}{$\begin{array}{l}\text { Types of food } \\
\text { premises }\end{array}$} & \multicolumn{7}{|c|}{ Food items } \\
\hline & & Rice (6) & Meat (6) & Fish (6) & Vegetable (6) & Egg (6) & Singara (6) & Puri (6) \\
\hline \multirow{3}{*}{ Gram-positive Bacteria } & SFP & + & + & + & + & - & + & - \\
\hline & GR & + & + & + & + & - & + & - \\
\hline & HCR & + & - & - & + & - & + & - \\
\hline \multirow{3}{*}{ Gram-negative Bacteria } & SFP & + & + & + & + & - & + & - \\
\hline & GR & - & - & + & + & - & + & - \\
\hline & HCR & - & - & - & + & - & + & - \\
\hline \multirow[t]{2}{*}{ Fungi } & GR & - & - & - & + & - & + & + \\
\hline & HCR & - & - & - & - & - & + & + \\
\hline
\end{tabular}

Table 1. Continued.

\begin{tabular}{|c|c|c|c|c|c|c|c|}
\hline \multirow{2}{*}{ Types of Microorganisms } & \multirow{2}{*}{$\begin{array}{l}\text { Types of food } \\
\text { premises }\end{array}$} & \multicolumn{6}{|c|}{ Food items } \\
\hline & & Dal (6) & Peaju (6) & Salad (6) & Fruit juices (6) & Sauces (6) & water (6) \\
\hline \multirow{3}{*}{ Gram-positive Bacteria } & SFP & + & - & + & + & + & + \\
\hline & GR & - & + & + & + & - & + \\
\hline & HCR & - & + & + & - & - & - \\
\hline \multirow{3}{*}{ Gram-negative Bacteria } & SFP & + & - & + & + & + & - \\
\hline & GR & - & + & + & - & - & - \\
\hline & HCR & - & - & + & - & - & - \\
\hline \multirow{3}{*}{ Fungi } & SFP & - & + & + & + & + & + \\
\hline & GR & - & + & + & - & - & + \\
\hline & HCR & - & - & + & - & - & - \\
\hline
\end{tabular}

(+) present.

(-) absent.

\subsection{Microbial Contamination Rate (\%) in Collected Food Sample}

Figure 1 shows the contamination rate of food samples from different food premises. Higher percentages of microbial contamination were observe in street side food premises $(76.92 \%$ for gram-positive bacteria, $69.23 \%$ for gram-negative bacteria and $61.54 \%$ for fungi). Another two groups also showed a moderate percentages of microbial contamination. This results indicate that the overall food handling, processing, hygiene and sanitation management in all food premises were very poor.
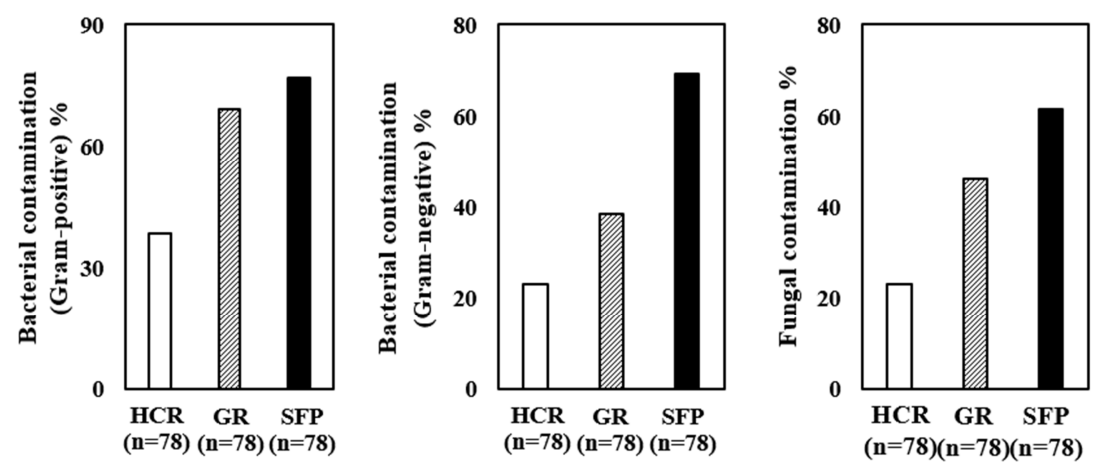

Figure 1. Microbial contamination rate (\%) in collected food sample.

\section{Discussion}

The microbial load and the presence of the bacterial pathogens in foods are a good indication of the food quality and the potential health risk they pose to consumers [17]. Reports indicates that street-vended foods contain different bacterial pathogen and fungus [18-20]. We also have found a huge number of bacteria and fungus in most common foods 
including rice, vegetable and salad. Foods are contaminated by different bacteria and fungus due to poor hygiene and sanitation management. Dust and dirty wearing cloths also responsible for the microbial contamination of street side foods. We found a higher number of gram-positive bacteria in food samples (10 item contaminated out of 13) compare to the gram-negative bacteria (9 item contaminated out of 13) and fungus (10 item contaminated out of 13). Report indicate that microbial food borne illness is highly associated with street foods [9]. We also found that street side foods were highly contaminated $(76.92 \%$ for gram-positive bacteria, $69.23 \%$ for gram-negative bacteria and $61.54 \%$ for fungi) compare to general restaurants $(69.23 \%$ for gram-positive bacteria, $38.46 \%$ for gram-negative bacteria and $46.15 \%$ for fungi) and higher classes restaurants $(38.46 \%$ for grampositive bacteria, $23.08 \%$ for gram-negative bacteria and $23.08 \%$ for fungi). All results suggested that microbial contamination in foods of different food premises occurred due to lack of the knowledge, practices and information about way of microbial contaminations, causes of food borne diseases, food safety, hygienic practices and sanitation management. Therefore, intake of such poor quality and unhygienic foods can lead touch kind of foods from the common restaurant foods calamitous diseases.

\section{Conclusions}

The present study was carried out to assess the microbial quality of food among different food premises. The collected foods were handled with much delicacy to avoid any kind of contamination. All the precautions, protocols and safety instructions were followed very strictly. After finishing all the works with those samples, they were preserved safely so that if any result went wrong or anyone wanted to analyze or investigate them further, can be done. Finally, people should become more aware in having foods from outside, selling and preparing the foods should also become more alert and food safety rules and implementation of food regulatory laws in food preparation, serving and preservation should be strongly maintained to avoid contamination problems and food-borne diseases.

\section{References}

[1] WHO's first ever global estimates of foodborne diseases find children under 5 account for almost one third of deaths, 3 December 2015.

[2] Afoakwa, E. O. (2005). Enhancing the quality of school feeding programme in Ghana. "The Global Child Nutrition Forum 2005. Baltimore, Maryland, USA.

[3] Oranusi, S., Umoh, V. J., \& Kwaja, J. K. P. (2007). Energy intake and anthropometry: a case study of families in Zaria, Nigeria. AJB, 6 (4), 459e464.

[4] Santana, N. G., Almeida, R. C. C., Ferreira, S. J., \& Almeida, F. P (2009). Microbiological quality and safety of meals served to children and adopted good manufacturing practices in public school catering in Brazil. Food Control, 20 (2009), 255e261.
[5] WHO, 2002. Foodborne diseases, emerging. Fact Sheet No. 124.

[6] Dablool, A. S., Fouad, M. A., \& Mihdhir, A. A. (2014). The effect of method of cooking and holding conditions on enterotoxin production by Staphylococcus aureus in two types of Saudi rice. European Academic Research, II (2).

[7] Panisello, P. J., Rooney, R., Quantick, P. C., \& StanwellSmith, R. (2000). Application of foodborne disease outbreak data in the development and maintenance of HACCP systems. International Journal of Food Microbiology, 59, 221e234.

[8] Sumner, S., Brown, L. G., Frick, R., Stone, C., Carpenter, L. R., Bushnell, L., et al. (2011). Factors associated with food workers working while experiencing vomiting or diarrhoea. Journal of Food Protection, 74 (2), $215 \mathrm{e} 220$.

[9] S Biswas, M A K Parvez, M Shafiquzzaman, S Nahar, M N Rahman, Isolation And Characterization Of Escherichia Coli In Ready-To-Eat Foods Vended In Islamic University, Kushtia, 2010, J. bio-sci. 18: 99-103.

[10] Oladipo IC1, Adeleke DT, Adebiyi AO (2010). The effect of $\mathrm{pH}$ and chemical preservatives on the growth of bacterial isolates from some Nigerian packaged fruit juices. Pak J Biol Sci. 13 (1): 16-21.

[11] Rane S. Street vended food in developing world: hazard analyses. Indian J Microbiol. 2011 Jan; 51 (1): 100-6.

[12] Mensah P, Yeboah-Manu D, Owusu-Darko K and Ablordey A (2002). Street foods in Accra, Ghana: how safe are they?. Bull World Health Organ. 80 (7): 546-54.

[13] Nazni P and Jaganathan A, Study On Microbial Analysis Of Street-Vended Food Samples Sold In Salem District, 2014, International Journal of Research in Biological Sciences.

[14] Meldrum, R. J., Little, C. L., Sagoo, S., Mithani, V., McLauchlin J. and De Pinna, E. 2009. Assessment of the microbiological safety of salad vegetables and sauces from kebab take-away restaurants in the United Kingdom. Food Microbiol, 26: 573-577.

[15] Shiklomanov, I. A. (2000). "Appraisal and Assessment of World Water Resources" (PDF). Water International. International Water Resources Association. pp. 11-32.

[16] Glass, R. I. and Black, R. E. 1992. The epidemiology of cholera. In: Barua D, Greenough WB III, editors. Cholera. New York: Plenum, pp. 129-54.

[17] Rosmini, M. R., Signori, M. L., Schneider, R., and Bonazza, J. C. 2004. Evaluation of two alternative techniques for counting mesophilic aerobic bacteria in raw milk. Food Control, 15 (1): $39-44$.

[18] Nichols, G. L., C. L. Little, V. D. E. Mithani and J. Louvois, 1999. The microbiological quality of cooked rice from restaurants and take-away premises in the United Kingdom. Journal of Food Protection. 62: 877-882.

[19] King, L. K., B. Awumbila, E. A. Canacoo and S. Ofosu Amaah, 2000. An assessment of the safety of street foods in the $\mathrm{Ga}$ district of Ghana: Implications for the spread of zoonoses. Acta Tropica, 76: 39-43.

[20] Kubheka, L. C., F. M. Mosupye and A. Von Holy, 2001. Microbiological survey of street-vended salad and gravy in Johannesburg city, South Africa. Journal of Food Control. 12: 127-131. 